\title{
A PERSPECTIVE REVIEW ON APPLICATIONS OF NANOPARTICLE MEDIATED DRUG DELIVERY TO THE CNS
}

\author{
V. KEERTHANA1, S. DHANALAKSHMI², N. HARIKRISHNAN³ \\ ${ }^{1}$ Pharma Buddy, ${ }^{2}$ Department of Pharmacognosy, ${ }^{3}$ Department of Pharmaceutical Analysis, Faculty of Pharmacy, Dr. M. G. R Educational \\ and Research Institute, Velappanchavadi, Chennai 600077 \\ Email: keerthuvijay10@gmail.com \\ Received: 12 Aug 2019, Revised and Accepted: 25 Oct 2019
}

\begin{abstract}
Delivery of drugs into the brain is one of the most interesting and challenging areas of research. The blood-brain barrier (BBB) is a highly selective semipermeable membrane that separates blood from the brain in the central nervous system. It acts as a barrier to protect the brain from microbes, neurotoxins and other chemical substances and also blocks the entry of many drugs into the brain. An estimated 6.8 billion people die every year from CNS diseases like Parkinson's disease, Alzheimer's disease, sclerosis, brain stroke, dementia and others. According to WHO, one billion people are affected worldwide, about 50 million suffer from epilepsy and 24 million suffer from Alzheimer and other dementias. This indicates the importance of the delivery of drugs into the brain for treating various neurological diseases and psychological disorders. In drug targeting, a concept was introduced by Dr. Paul Ehrlich as a 'magic bullet' that gave tremendous hope for the researches to deliver drugs into the brain. This review discuses about various drug targeting strategies and applications of nanotechnology in designing drug delivery systems with the ability to cross through the BBB for treating neurological diseases.
\end{abstract}

Keywords: BBB, CNS, Brain target, Nanoparticles, TDDS, Neural diseases

(C) 2020 The Authors. Published by Innovare Academic Sciences Pvt Ltd. This is an open-access article under the CC BY license (http://creativecommons.org/licenses/by/4.0/) DOI: http://dx.doi.org/10.22159/ijcpr.2020v12i1.36819. Journal homepage: https://innovareacademics.in/journals/index.php/ijcpr

\section{INTRODUCTION}

Worldwide, Alzheimer's and Parkinson's disease are the most commonly caused neurodegenerative diseases. Stroke is one of the second leading cause of death and the third leading cause of disability. An estimated 6.8 billion people die every year from central nervous diseases like Parkinson's disease, Alzheimer's disease, sclerosis, brain stroke, dementia and others $[1,2]$. According to WHO, one billion people are affected worldwide, about 50 million suffer from epilepsy and 24 million suffer from Alzheimer's and other dementias.

The primary phase in the therapy of neural illness is the diffusion of drugs across the BBB. The safe, appropriate and targeted delivery of drug compounds into the brain is a challenging and exceptional goal for achieving optimal therapeutic outcomes against neural diseases [3]. There are various drug targeting strategies into the brain. Nanoparticle is considered one of the most efficient carriers to transport the therapeutic agent to the targeted site [4].

\section{Blood-brain barrier}

Human brain is the most delicate and complicated organ in the body that is protected by a membrane called the blood-brain barrier (BBB). The BBB is a highly selective semipermeable membrane that separates the circulating blood from the brain in the central nervous system $[5,6]$. This barrier protects the brain neurons from harmful toxins, microbes and other chemicals that exist in the blood. This barrier also blocks the diffusion of drugs into the brain.

The BBB is composed of tightly connected endothelial cells and a discontinuous layer of pericytes. Endothelial cells consist of specific proteins TJs and AJs [7]. TJs proteins include claudins, occludens, zona occludens, junction adhesion molecules (JAMs).

Our human brain consists of about 100 billion neurons. The capillaries may be 7-10 $\mu \mathrm{m}$ in diameter. The BBB does have any intracellular and valvar gaps and the entry of any compounds into the brain is very limited $[8,9]$. The BBB only enables the passage of ions or neurotransmitters responsible for the impulse conduction. However, nanoparticles (NPs) coupled with polymeric materials, can pass through the $\mathrm{BBB}$ and promotes the delivery of drugs into the CNS [10].

\section{Dr. Paul ehrlich's magic bullet concept}

Dr. Paul Ehrlich, a German-jewis physician introduced a concept named as magic bullet concept in 1990. For a drug to act on a particular targeted site, it requires a proper carrier [11, 12]. This carrier has to be bound with the drug and should reach the site of action to produce its therapeutic effect but it should not affect the non-targeted sites or non-diseased cells [13].

Dr. Paul Ehrlich termed that a carrier-drug complex should act only on the targeted site just as the bullet target a specific point [14]. This concept gave tremendous hope for scientists for achieving the passage of drugs through the BBB.

\section{Substance transport across the BBB}

Because of the presence of BBB, which limits the entry into the brain, prevents the brain from diseases and does not allow the access of various pharmaceutical agents into the brain. The BBB blocks the passage of even tiny molecules to enter into the brain [15]. It only allows the passage of ions or molecules that are responsible for the impulse conduction and synthesis and release of neurotransmitters.

The passage of molecules across the BBB occurs through two processes. They either pass through the endothelial cells or is termed as trans cellular transportation or the pass in between the endothelial cells and it is termed as paracellular transportation.

There are various drug targeting strategies to pass through the BBB. These are enlisted in table 1 . There are mainly two techniques noninvasive and invasive techniques. Each technique has different approaches and may have advantages and disadvantages within itself. Hence for a successful target of drugs to the CNS is based on the proper selection of these approaches [16].

Nanoparticles acts an efficient carrier for the transport of pharmaceutical compounds to the brain. Several nano-formulations are used to penetrate through the BBB. The nanoparticles penetrate through the tight junctions between the endothelial cells and allow the drug to pass through the BBB [17]. 
Table 1: Approach and strategies for central nervous system drug delivery

\begin{tabular}{|c|c|c|c|}
\hline Techniques for the drug delivery to the CNS & Approaches & Strategies & References \\
\hline \multirow[t]{13}{*}{ Non-invasive techniques } & Chemical & Lipophilic analogues & [18] \\
\hline & & Prodrugs & \\
\hline & & Chemical drug delivery system & \\
\hline & & Molecular packing & \\
\hline & Biological & Receptor-mediated delivery of chimeric peptides & [19] \\
\hline & & Viral vector & \\
\hline & & Cell-penetrating peptide-mediated delivery & \\
\hline & Colloidal & Micelles and microemulsions & {$[20]$} \\
\hline & & Nanospheres and nano-capsules & \\
\hline & & Liposomes & \\
\hline & & SLNs & \\
\hline & & Dendrimers & \\
\hline & & Polyetheleneimine derivatives & \\
\hline \multirow[t]{9}{*}{ Invasive techniques } & Pharmacological & Intracerebral implants & {$[21]$} \\
\hline & & $\begin{array}{l}\text { Intraventricular/intrathecal/interstitial delivery } \\
\text { Biological tissue delivery }\end{array}$ & \\
\hline & Blood-brain barrier & Convection-enhanced delivery & {$[22]$} \\
\hline & disruption & Osmotic blood-brain barrier disruption strategy & \\
\hline & & Biochemical blood-brain barrier disruption strategy & \\
\hline & & $\begin{array}{l}\text { Ultrasound mediated blood-brain barrier disruption } \\
\text { strategy }\end{array}$ & \\
\hline & Alternative routes & Olfactory and trigeminal pathways & {$[23]$} \\
\hline & & Intranasal delivery & \\
\hline & & Intophoretic delivery & \\
\hline
\end{tabular}

\section{Nanoparticles}

Nanoparticles are colloidal carriers. They may be the natural or synthetic origin. The natural NPs are either prepared from chitosan or albumin. Synthetic NPs are prepared from polymeric materials like polyethyleneimine (PEI), polyalkylanoacrylates (PAA), polylactic glycolic acid (PLGA), dendrimers. NPs are also synthesized from inorganic materials like gold and silica.

Nanoparticles are developed to regulate the release and safeguard of drugs from enzymatic or chemical degradation and to improve its therapeutic efficacy. Several kinds of nanoparticles can be used to deliver drugs and genes to the CNS [24].

\section{Characteristics of nanoparticles}

Molecules with high lipophilicity and small size can passively pass across the BBB. Lipophilicity of NPs are often associated with the permeability and solubility of a compound. Lipophilicity, however, is a two-edged sword. Most drug parameters are affected by lipophilicity [25]. Increased lipophilicity leads to the formation of compounds with rapid metabolism, low solubility and poor absorption. In such cases, nanotechnology can be used for the delivery of these pharmaceutical compounds. New strategies were developed for the delivery of nanoformulations (fig. 1.).

\section{Nanoparticle mediated drug delivery [26]}

The nanoparticles due to their mean particle size, zeta potential and hydrophilicity play a major role for the transport of drugs. Due to their small size, they can be easily penetrated through the BBB. To increase the permeability of NPs they are coated with surfactants like polysorbate 80 . This enhanced the permeability of drugs like loperamide, tubocurarine and doxorubicin [27]. Attachment of ligands such as shielding ones can increase their circulation time in the blood whereas targeting ligands enhances the targeting potential.

Claudia et al. An experiment was carried out on mice. Meloxicam, a drug used in the treatment of memory impairment cannot diffuse through the BBB. Hence, it is loaded with nano-capsules and was found to induce memory impairment in mice [28].

Gurthork et al. an effective nanosystem was developed for efficient drug delivery to the brain. The designed a liposomal drug delivery system for transferring levodopa (used to treat Parkinson's disease) through the BBB.

Various nanoformulations were developed in order to increase the permeability and efficacy of drugs. These are enlisted in table 2 .

Table 2: Various nanoformulations for the CNS drug delivery

\begin{tabular}{|c|c|c|c|c|c|c|}
\hline $\begin{array}{l}\text { S. } \\
\text { No. }\end{array}$ & Title & Journal name & Author & $\begin{array}{l}\text { Year/volu } \\
\text { me/Issue }\end{array}$ & $\begin{array}{l}\text { Nano formulation } \\
\text { (TDDS) }\end{array}$ & Conclusion \\
\hline 1. & $\begin{array}{l}\text { Polymeric nanoparticles } \\
\text { for drug delivery to the } \\
\text { CNS }\end{array}$ & $\begin{array}{l}\text { Advanced drug } \\
\text { delivery }\end{array}$ & Toral patel & $\begin{array}{l}2011 / 12 / \\
006\end{array}$ & $\begin{array}{l}\text { PBCA nanoparticle coated with } \\
\text { polysorbate } 80 \text { were loaded } \\
\text { with dalargin (opiod activity) }\end{array}$ & $\begin{array}{l}\text { Dalargin-loaded PBCA diffuses } \\
\text { through the BBB and reaches } \\
\text { the targeted site. }\end{array}$ \\
\hline 2. & $\begin{array}{l}\text { Polymeric nanoparticles for } \\
\text { drug delivery to the CNS }\end{array}$ & $\begin{array}{l}\text { Advanced drug } \\
\text { delivery }\end{array}$ & Toral patel & $\begin{array}{l}2011 / 12 / \\
006\end{array}$ & $\begin{array}{l}\text { PLA nanoparticles loaded with } \\
\text { breviscapine (flavonoid) }\end{array}$ & $\begin{array}{l}\text { PLA-loaded breviscapine } \\
\text { penetrates the BBB }\end{array}$ \\
\hline 3. & $\begin{array}{l}\text { Nanoparticles for brain } \\
\text { drug delivery. }\end{array}$ & $\begin{array}{l}\text { ISRN } \\
\text { biochemistry }\end{array}$ & Massimo & 2013 & $\begin{array}{l}\text { Rifampicin drug loaded with } \\
\text { NPs }\end{array}$ & $\begin{array}{l}\text { Expt. carried out on mice } \\
\text { showed better permeability of } \\
\text { rifampicin into the brain }\end{array}$ \\
\hline 4. & $\begin{array}{l}\text { Nano formulations for } \\
\text { drug delivery }\end{array}$ & $\begin{array}{l}\text { biopharmaceut } \\
\text { ics }\end{array}$ & wang & 2015 & $\begin{array}{l}\text { Synthesis of DU-FUdR to } \\
\text { overcome the limited access of } \\
\text { drug FUdR and incorporated } \\
\text { with SLN }\end{array}$ & $\begin{array}{l}\text { The result showed that D0- } \\
\text { FUdR-SLN had brain target } \\
\text { efficiency in vivo. }\end{array}$ \\
\hline 5. & $\begin{array}{l}\text { Nanoparticle mediated } \\
\text { drug delivery }\end{array}$ & $\begin{array}{l}\text { Journal of } \\
\text { controlled } \\
\text { release }\end{array}$ & claudia & $\begin{array}{l}2016 / 34- \\
47\end{array}$ & NGF loaded with PBCA NPs & $\begin{array}{l}\text { Improved uptake to brain } \\
\text { regions. Reversed Scopolamaine- } \\
\text { induced amnesia and improved } \\
\text { cognition and memory. }\end{array}$ \\
\hline
\end{tabular}




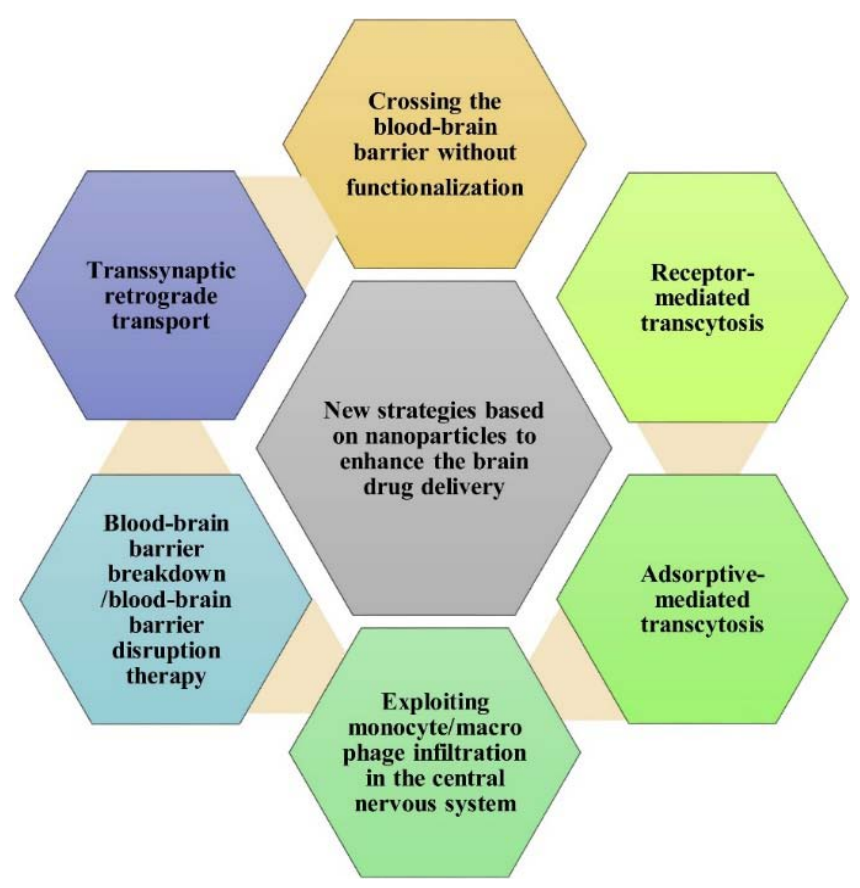

Fig. 1: Development of new strategies based on NPs for drug delivery into the CNS

\section{Conclusion and future prospects}

NPs are well suited for the diagnosis and therapy of brain disorders owing to their physical, chemical and biological characteristics [29]. The ability to use this technological strategy for the therapy and diagnosis of CNS illnesses was hopeful. Several nanoformulations are being investigated using polymer-based techniques and nanomaterials [30].

\section{ACKNOWLEDGMENT}

The authors are thankful to Dr. MGR. Educational and Research Institute for providing facilities and encouragement.

\section{AUTHORS CONTRIBUTIONS}

All the authors have contributed equally.

\section{CONFLICT OF INTERESTS}

Declare none

\section{REFERENCES}

1. M Srikanth, JA Kessler. Nanotechnology-novel therapeutics for CNS disorders. Nat Rev Neurol 2012;8:307.

2. M Vijayan, PH Reddy. Stroke, vascular dementia, and Alzheimer's disease: molecular links. J Alzheimer Dis 2016;54:427-43.

3. Kabanov H Gendelman. Nanomedicine in the diagnosis and therapy of neurodegenerative disorders. Prog Polym Sci 2007;32:1054-82.

4. Nazem GA Mansoori. Nanotechnology solutions for Alzheimer's disease: advances in research tools, diagnostic methods and therapeutic agents. J Alzheimer Dis 2008;13:199-223.

5. P Flachenecker. Epidemiology of neuroimmunological diseases. J Neurol 2006;253:v2-v8.

6. NJ Abbott, AAK Patabendige, DEM Dolman, SR Yusof, DJ Begley. Structure and function of the blood-brain barrier. Neurobiol Dis 2010;37:13-25.

7. J Boyer Di Ponio, F El Ayoubi, F Glacial, K Ganeshamoorthy, C Driancourt, M Godet, et al. Instruction of circulating endothelial progenitors in vitro towards the specialized blood-brain barrier and arterial phenotypes. PLoS One 2014;9:e84179.

8. JD Huber, KA Witt, S Hom, RD Egleton, KS Mark, TP Davis. Inflammatory pain alters blood-brain barrier permeability and tight junctional protein expression. Am J Physiol Heart Circ Physiol 2001;280:H1241-H1248.
9. H Wolburg, A Lippoldt. Tight junctions of the blood-brain barrier: development, composition and regulation. Vasc Pharmacol 2002;38:323-37.

10. Y Persidsky, SH Ramirez, J Haorah, GD Kanmogne. Blood-brain barrier: structural components and function under physiologic and pathologic conditions. J Neurol Immune Pharmacol 2006; 1:223-36

11. YK Choi, KW Kim. Blood-neural barrier: its diversity and coordinated cell-to-cell communication. BMB Rep 2008;41: 345-52.

12. Alvarez-Buylla, JM Garcia-Verdugo. Neurogenesis in adult subventricular zone. J Neurosci 2002;22:629-34.

13. M Tavazoie, L Van der Veken, V Silva Vargas, M Louissaint, L Colonna, B Zaidi, et al. A specialized vascular niche for adult neural stem cells. Cell Stem Cell 2008;3:279-88.

14. MC Whitman, W Fan, L Rela, DJ Rodriguez Gil, CA Greer. Blood vessels form amigratory scaffold in the rostral migratory stream. J Comp Neurol 2009;516:94-104.

15. L Bennett, M Yang, G Enikolopov, L Iacovitti. Circumventricular organs: a novelsite of neural stem cells in the adult brain. Mol Cell Neurosci 2009;41:337-47.

16. Hourai S Miyata. Neurogenesis in the circumventricular organs of adult mouse brains. J Neurosci Res 2013;91:757-70.

17. R Lin, J Cai, C Nathan, X Wei, S Schleidt, R Rosenwasser, et al. Neurogenesis is enhanced by stroke in multiple new stem cell niches along the ventricular system at sites of high BBB permeability. Neurobiol Dis 2015;74:229-39.

18. H Xin, X Sha, X Jiang, L Chen, $\mathrm{K}$ Law, J Gu, et al. The brain targeting mechanism of angiopep-conjugated poly(ethylene glycol)-copoly(e\{open\}-caprolactone) nanoparticles. Biomaterials 2012; 33:1673-81.

19. JV Georgieva, D Kalicharan, PO Couraud, IA Romero, B Weksler, D Hoekstra, et al. Surface characteristics of nanoparticles determine their intracellular fate in and processing by human blood-brain barrier endothelial cells in vitro. Mol Ther 2011;19:318-25.

20. R Gromnicova, HA Davies, P Sreekanthreddy, IA Romero, T Lund, IM Roitt, et al. Glucose-coated gold nanoparticles transfer across human brain endothelium and enter astrocytes in vitro. PLoS One 2013;8:e81043.

21. X Gao, J Qian, S Zheng, Y Changyi, J Zhang, S Ju, et al. Overcoming the blood-brain barrier for delivering drugs into the brain by using adenosine receptor nanoagonist. ACS Nano 2014;8:3678-89. 
22. P Decuzzi, B Godin, T Tanaka, SY Lee, C Chiappini, X Liu, et al. Size and shape effects in the biodistribution of intravascularly injected particles. J Controlled Release 2010;141:320-7.

23. S Aday, R Cecchelli, D Hallier Vanuxeem, MP Dehouck, L Ferreira. Stem cell-based human blood-brain barrier models for drug discovery and delivery. Trends Biotechnol 2016;34:382-93.

24. R Cecchelli, S Aday, E Sevin, C Almeida, M Culot, L Dehouck, et al. A stable and reproducible human blood-brain barrier model derived from hematopoietic stem cells. PLoS One 2014; 9:e99733.

25. H Cho, JH Seo, KHK Wong, Y Terasaki, J Park, K Bong, et al. Three-dimensionalblood-brain barrier model for in vitro studies of neurovascular pathology. Sci Rep 2015;5:15222.

26. Q Liu, J Hou, X Chen, G Liu, D Zhang, H Sun, et al. P-glycoprotein mediated efflux limits the transport of the novel antiParkinson's disease candidate drug FLZ across the physiological and PD pathological in vitro BBB models. PLoS One 2014;9:e102442.

27. Freese S Reinhardt, G Hefner, RE Unger, CJ Kirkpatrick, K Endres. A novel blood-brain barrier co-culture system for drug targeting of Alzheimer's disease: establishment by using acitretin as a model drug. PLoS One 2014;9:91003.

28. S Syvanen, O Lindhe, M Palner, BR Kornum, O Rahman, B Langström, et al. Spe-cies differences in blood-brain barrier transport of three positron emission tomog-raphy radioligands with emphasis on P-glycoprotein transport. Drug Metab Dispos 2009;37:635-43.

29. L Yang, KK Shah, TJ Abbruscato. An in vitro model of ischemic stroke. Methods Mol Biol 2012;814:451-66.

30. B Etame, CA Smith, WC Chan, JT Rutka. Design and potential application of PEGylated gold nanoparticles with sizedependent permeation through brain microvasculature. Nanomedicine 2011;7:992-1000. 